\title{
Transcriptomic analysis of circulating neutrophils in metabolically stressed peripartal grazing dairy cows
}

\author{
M. A. Crookenden, ${ }^{1,2 *}$ K. M. Moyes, ${ }^{3}$ B. Kuhn-Sherlock, ${ }^{1}$ K. Lehnert, ${ }^{2}$ C. G. Walker, ${ }^{1} \dagger$ J. J. Loor, ${ }^{4}$ \\ M. D. Mitchell, ${ }^{5}$ A. Murray, ${ }^{6}$ V. S. R. Dukkipati, ${ }^{6}$ M. Vailati-Riboni, ${ }^{4}$ A. Heiser,,${ }^{6,7}$ and J. R. Roche ${ }^{1,2} \ddagger$ \\ ${ }^{1}$ DairyNZ Ltd., Hamilton, New Zealand 3284 \\ ${ }^{2}$ School of Biological Sciences, University of Auckland, New Zealand 1010 \\ ${ }^{3}$ Department of Animal and Avian Sciences, University of Maryland, College Park 20742 \\ ${ }^{4}$ Department of Animal Sciences, University of Illinois, Urbana 61801 \\ ${ }^{5}$ University of Queensland, Centre for Clinical Research, Herston, Australia 4029 \\ ${ }^{6}$ Institute of Veterinary, Animal, and Biomedical Sciences, Massey University, Palmerston North, New Zealand 4442 \\ ${ }^{7}$ AgResearch, Hopkirk Research Institute, Palmerston North, New Zealand 4442
}

\section{ABSTRACT}

The high metabolic demand during the transition into lactation places cows at greater risk of metabolic and infectious disease than at any other time in their lactation cycle. Additionally, a change occurs in the innate immune response during this period, which contributes to increased risk of disease. In the current study, we compared the transcriptomes of neutrophils from dairy cows divergent in their metabolic health post-calving. Cows ( $\mathrm{n}=5$ per risk group) were selected from a parent experiment $(\mathrm{n}=45$ cows). Those with high or low concentrations of plasma nonesterified fatty acids, plasma $\beta$-hydroxybutyrate, and liver triacylglycerol in both wk 1 and 2 were deemed to be at "high risk" (HR) or "low risk" (LR) of metabolic dysfunction, respectively. Circulating neutrophils were isolated at 3 time points during the transition period ( $\mathrm{d} 0$ and wk 1 and 4 post-calving), and gene expression was analyzed using RNA sequencing. Differential gene expression between the risk groups was determined using edgeR (http://bioconductor.org), and pathway analysis was conducted using Ingenuity Pathway Analysis (Ingenuity Systems, Qiagen, Valencia, CA). Statistical analysis indicated no interaction between risk and week. Therefore, the overall effect of risk was analyzed across all time points. In total, 3,500 genes were differentially expressed between the HR and LR cows (false discov-

Received January 24, 2019

Accepted April 19, 2019.

*Corresponding author: mallory.crookenden@agresearch.co.nz

$\dagger$ Current address: Growing Up in New Zealand, University of Auckland, New Zealand 1072.

$\ddagger$ Current address: Ministry for Primary Industries, Wellington, New Zealand 6011. ery rate $<0.05)$. Of these, 2,897 genes were identified by Ingenuity Pathway Analysis and used for pathway analysis. Of the relevant pathways identified, neutrophils isolated from HR cows showed downregulation of genes involved in the recruitment of granulocytes, interferon signaling, and apoptosis, and upregulation of genes involved in cell survival. The results indicate that metabolically stressed cows had reduced neutrophil function during the peripartum period, highlighting a potential relationship between subclinical metabolic disease and innate immune function that suggests that metabolic health negatively affects the innate immune system and may contribute to the state of immunosuppression during the peripartum period. In this way, the metabolic stress among the HR cows may reduce their ability to combat infection during the transition period. Key words: peripartum health, RNA sequencing, PMN

\section{INTRODUCTION}

A successful transition between pregnancy and lactation in dairy cows requires several complex metabolic and physiological changes to occur in concert. If these changes are not sufficiently coordinated, the animals experience metabolic stress and health dysfunction, whether subclinical or clinical (Sordillo et al., 2009; LeBlanc, 2010). The incidence of health dysfunction during the transition period can be very high: 30 to $50 \%$ of cows, or more, may experience metabolic or infectious disease during the transition period, and the incidence of subclinical disease is, likely, grossly underestimated (LeBlanc, 2010; Compton et al., 2014), highlighting how precarious a successful transition can be.

A balanced inflammatory state during the transition period is required for a successful transition that is free of complications (Challis et al., 2009; Farney et al., 
2013; Vailati-Riboni et al., 2015). Parturition involves inflammatory events that modify local and systemic immune responses (Molloy et al., 2004; Christiaens et al., 2008). Hence, the ability to restore homeostasis after parturition is essential, because persistent or excessive inflammation can increase the risk of health disorders during the transition period (Sordillo and Raphael, 2013). Neutrophils are mediators of the inflammatory response; therefore, their function is associated with the outcome of peripartal conditions, such as retained placenta and uterine infection (Kimura et al., 2002; Hammon and Goff, 2006). We and others have demonstrated altered gene and protein expression in peripheral blood leukocytes during the transition period (Burton et al., 1995; Heiser et al., 2015; Crookenden et al., 2016). As neutrophils are important regulators of the innate immune response, their number and performance regulate the outcome of infections during the transition period.

Metabolic changes during the transition period cause a state of negative energy balance in early lactation, a state observed by most lactating dairy cattle (Drackley, 1999). This is accompanied by the mobilization of nonesterified fatty acids (NEFA) from adipose tissue reserves and increased production of BHB by the liver. Severe negative energy balance that causes extended adipose mobilization leads to NEFA accumulation in the liver as triacylglycerol (TAG), which impedes liver function (Vazquez-Añon et al., 1994). Uncontrolled lipid mobilization may be associated with the pathogenesis of health disorders during the transition period (Drackley, 1999). In extreme cases, the metabolic condition (high levels of NEFA, BHB, and liver TAG) can be likened to cardiovascular disease and type 2 diabetes in humans (Blaak, 2003; Desideri-Vaillant et al., 2004; Pilz and März, 2008). Furthermore, an interaction between metabolic stress, inflammation, and immune function exists during the transition period (Sordillo and Aitken, 2009; Sordillo et al., 2009). Therefore, these metabolites are suitable proxies for metabolic health status during the transition period.

These metabolic factors also affect the innate immune system. For example, high concentrations of NEFA have negative effects on neutrophil function in vitro (Scalia et al., 2006), severe fatty liver can lower production of reactive oxygen species and expression of cell surface molecules in neutrophils in vivo (Zerbe et al., 2000), and high BHB concentrations (in vitro) have been demonstrated to inhibit chemotaxis in ovine neutrophils and bovine leukocytes (Sartorelli et al., 1999; Suriyasathaporn et al., 1999). These changes in neutrophil responses are associated with gene expression changes involved in cellular function that reportedly occur over the transition period in both high-yielding housed cows (Kehrli et al., 1989; Burton et al., 2001) and moderate-yielding grazing dairy cows (Crookenden et al., 2016). Therefore, we hypothesized that metabolic stress would affect the neutrophil transcriptome. To test this hypothesis, we selected 2 groups of cows divergent in metabolic health (assessed via plasma NEFA, $\mathrm{BHB}$, and liver TAG) and used RNA sequencing to investigate changes in the transcriptome of circulating neutrophils in these cows at 3 time points over the transition period (post-calving on the day of parturition, wk 1 , and wk 4). The objective was to investigate the effect of metabolic stress, as indicated by subclinical health dysfunction, on the transcriptome of circulating neutrophils in periparturient grazing dairy cows.

\section{MATERIALS AND METHODS}

\section{Experimental Design and Sample Collection}

The Ruakura Animal Ethics Committee (Hamilton, New Zealand) approved all animal manipulations (RAEC\#12799) in accordance with the New Zealand Animal Welfare Act (1999). A subset of cows of mixed age and breed (Holstein-Friesian and Holstein-Friesian $\times$ Jersey) were selected from the cows described in Crookenden et al. (2016). Cows ( $\mathrm{n}=5$ per group) were separated into "high risk" (HR) or "low risk" (LR) groups, based on significant divergence in their indicators of metabolic health at wk 1 and wk 2 post-calving: plasma concentrations of NEFA and BHB as well as liver TAG (Figure 1). Metabolic health indicators included plasma NEFA $<0.9 \mathrm{mmol} / \mathrm{L}$ in $\mathrm{LR}$ and $>1.2 \mathrm{mmol} / \mathrm{L}$ in $\mathrm{HR}$ animals at 1 wk post-calving. At wk 2, plasma NEFA concentrations $<0.6 \mathrm{mmol} / \mathrm{L}$ and $>0.7 \mathrm{mmol} / \mathrm{L}$ characterized LR and HR cows, respectively. Plasma $\mathrm{BHB} \leq 0.6 \mathrm{mmol} / \mathrm{L}$ and $>0.6 \mathrm{mmol} / \mathrm{L}$ at both wk 1 and 2 characterized LR and HR cows, respectively. At wk 1 and 2 post-calving, liver TAG $<2 \%$ (wt/wt) and $\geq 6 \%$ (wt/wt) characterized LR and HR cows, respectively, indicating fatty liver in HR animals (Shen et al., 2018). Metabolic cut-points have been evaluated in previous research and support increased risk of adverse health effects in transition cows (reviewed by McArt et al., 2013). All cows had a BCS of 4 or 5 at calving (based on a 10-point scale, equivalent to approximately 2.75 and 3.25 , respectively, on a 5-point scale; Roche et al., 2004) and were offered a diet of fresh pasture (average $\mathrm{DMI}=12.4 \pm 0.8 \mathrm{~kg} / \mathrm{d}$ ), supplemented with corn silage (average DMI $=0.8 \pm 0.8 \mathrm{~kg}$ of DM/d) and pasture silage (average $\mathrm{DMI}=1.1 \pm 1.0 \mathrm{~kg} \mathrm{DM} / \mathrm{d}$ ) post-calving. None of the cows experienced any symptoms of clinical disease or were treated for any medical conditions during the trial period. 

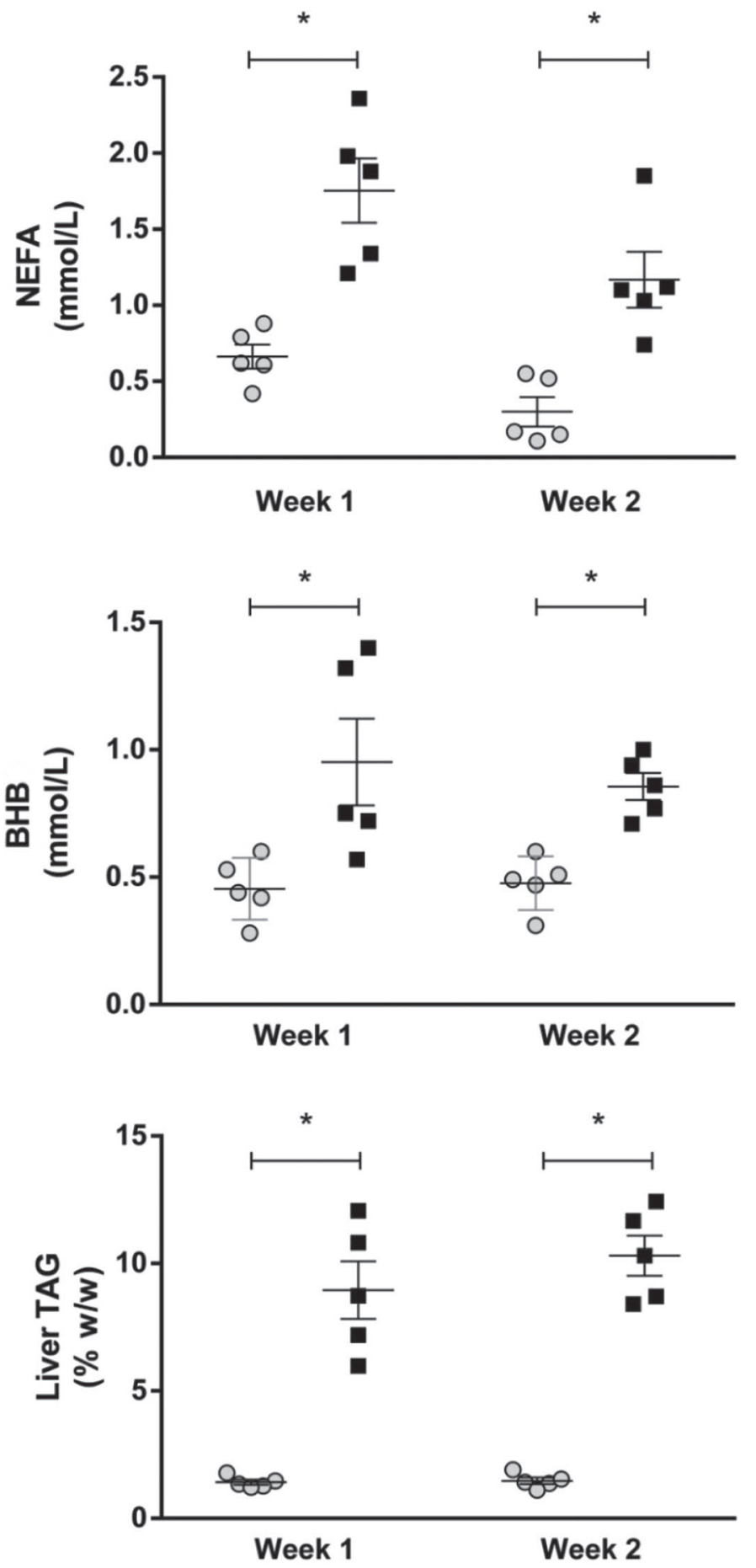

Time point post-calving

Figure 1. Indicators of metabolic health status for determining risk category. Concentrations of plasma nonesterified fatty acids (NEFA) plasma BHB, and liver triacylglycerol (TAG) for individual cows within risk groups [low risk $(\mathrm{LR})=$ gray circles; high risk $(\mathrm{HR})=$ black squares] to indicate distribution. Horizontal lines indicate the arithmetic mean, and error bars denote SEM. Significance between risk groups is indicated by an asterisk $(*)$, determined by one-way ANOVA at each time point. Significance was considered at $P<0.05$.

\section{Blood Sampling}

Blood was sampled from the coccygeal blood vessels for neutrophil isolation $(\sim 50 \mathrm{~mL} / \mathrm{cow})$ and metabolite analysis $(\sim 10 \mathrm{~mL} / \mathrm{cow})$ at 3 time points over the transition period; day of calving ( $\mathrm{d} 0$ ) and post-calving at wk $1[1 \mathrm{wk}(\mathrm{d} 7 \pm 1.6)]$ and wk 4 [4 wk $(\mathrm{d} 27 \pm 1.1)]$. Blood for neutrophil isolation was collected in 6 evacuated tubes (BD, Auckland, New Zealand) containing acid citrate dextrose (solution A; trisodium citrate $22.0 \mathrm{~g} / \mathrm{L}$, citric acid $8.0 \mathrm{~g} / \mathrm{L}$, dextrose $24.5 \mathrm{~g} / \mathrm{L}$ ). The tubes were inverted 8 times and placed immediately on ice until neutrophil isolation, which occurred within $2 \mathrm{~h}$ of blood collection. Blood for metabolite analysis was collected in evacuated tubes containing a lithium heparin anticoagulant. Tubes were inverted and placed immediately on ice; within $30 \mathrm{~min}$, blood tubes were centrifuged at $1,500 \times g$ for $12 \mathrm{~min}$ at $4^{\circ} \mathrm{C}$, and plasma was aspirated and stored at $-20^{\circ} \mathrm{C}$ until assayed.

\section{Liver Sampling for Triacylglycerol Analysis}

Liver tissue samples were collected from all cows by biopsy the week before calving (wk -1) and wk 1,2 , and 4 after calving. Briefly, the skin in the right 11th intercostal space at the level of the greater trochanter was shaved and disinfected, and the area was anesthetized with $7 \mathrm{~mL}$ of $2 \%$ lignocaine (Lopaine $2 \%$, lignocaine hydrochloride $20 \mathrm{mg} / \mathrm{mL}$, Ethical Agents, South Auckland, New Zealand). An incision was made through the skin, a 12 -gauge $\times 20$-cm biopsy needle was inserted into the liver, and approximately $1 \mathrm{~g}$ (wet weight) of liver tissue was collected. Liver samples were snap-frozen in liquid nitrogen and stored at $-80^{\circ} \mathrm{C}$.

\section{Neutrophil Isolation}

Neutrophils were isolated and checked for viability and differentials from all cows, according to procedures previously described in Crookenden et al. (2016). Briefly, blood collected in the acid citrate dextrose evacuated tubes was inverted and pooled (for each cow at each time point) by transfer into a $50-\mathrm{mL}$ conical tube. Tubes were centrifuged for $30 \mathrm{~min}$ at $850 \times g$ at $4^{\circ} \mathrm{C}$. The plasma, buffy coat, and up to one-third of the red blood cells (RBC) were aspirated by Pasteur pipette and discarded, leaving two-thirds of remaining RBC and neutrophils. Water (milliQ, Millipore, Billerica, MA) was added ( $25 \mathrm{~mL}$ ) and mixed for 10 to 30 s to lyse the RBC and $5 \mathrm{~mL}$ of $5 \times$ concentrated PBS ( $\mathrm{pH}$ 7.4, Life Technologies, Carlsbad, CA) was added to each tube to restore isotonicity. Tubes were spun at $330 \times g$ for $10 \mathrm{~min}$ at $4^{\circ} \mathrm{C}$, and supernatant was decanted to isolate the white cell pellet. The pellet was 
washed with $10 \mathrm{~mL}$ of $1 \times$ concentrated PBS $(\mathrm{pH} 7.4$, Life Technologies), vortexed, and centrifuged for $5 \mathrm{~min}$ at $660 \times g$ at $4^{\circ} \mathrm{C}$. If $\mathrm{RBC}$ remained, the water lysing step was repeated. Cells were resuspended in $5 \mathrm{~mL}$ of $1 \times$ PBS $(\mathrm{pH} 7.4)$, and $100 \mu \mathrm{L}$ was transferred into a 1.5-mL microcentrifuge tube (Raylab, Albany, New Zealand) and placed on ice for subsequent viability and staining assays. Cell differentials indicated an average of $79 \%$ granulocytes and $94 \%$ live cells with this isolation method (Crookenden et al., 2016). The 50-mL tubes were centrifuged again $\left(5 \mathrm{~min}\right.$ at $660 \times g$ at $4^{\circ} \mathrm{C}$ ), the liquid was decanted, and the cell pellet was resuspended in $1 \mathrm{~mL}$ TRIzol reagent (Life Technologies). The 1-mL cell suspension was transferred into a $2-\mathrm{mL}$ microcentrifuge tube (Eppendorf, Hamburg, Germany), placed immediately on ice, and stored at $-80^{\circ} \mathrm{C}$ for subsequent RNA extraction.

\section{RNA Extraction and Sequencing}

Total RNA from neutrophil lysates in the Trizol reagent was extracted according to the manufacturer's protocol, with details described previously (Crookenden et al., 2016). RNA quantity and purity were assessed using spectrophotometry (Nanodrop, Thermo Fisher Scientific, Waltham, MA). All RNA samples had a 260/280 ratio of greater than 1.90 and a 260/230 ratio of greater than 1.75 as an indication of high purity (Nanodrop, ThermoFisher Scientific). Quality of RNA was determined by capillary gel electrophoresis (Agilent 2100 Bioanalyzer, Agilent Technologies, Santa Clara, CA). Samples had an average RNA integrity number $( \pm \mathrm{SD})$ of $8.1 \pm 0.71$ and were stored at $-80^{\circ} \mathrm{C}$ until sequencing analysis.

Paired-end cDNA libraries were constructed using TruSeq stranded total RNA Library prep with RiboZero ribodepletion and "External RNA Controls Consortium (ERCC) spike-in" controls according to manufacturer's recommendations (Illumina, San Diego, CA). Libraries were sequenced on an Illumina HiSeq 2500 platform using 4 lanes; $2 \times 125$ bp paired-end reads using V4 chemistry (Illumina). Sequencing resulted in $1.65 \mathrm{~B}$ total paired reads, with a mean percentage of bases $\geq$ Q30 of $91.6 \%$, and a mean average quality score per base of 35.2 . Average library size $( \pm \mathrm{SD})$ was $339 \pm 17 \mathrm{bp}$, with the exception of sample 200 (268 bp library), which was collected during wk 4 . Library construction and sequencing was completed by New Zealand Genomics Ltd., Dunedin, New Zealand.

\section{Data Processing and Analysis}

Raw read quality was analyzed with FastQC (v. 0.11.2; Andrews, 2010), followed by removal of se- quencing adaptors and PCR primers with cutadapt (v. 1.9.1; Martin, 2011). Reads were trimmed to contiguous sequences with minimum Phred scores of 25 and a minimum final length of 50 nucleotides, using SolexaQA (v. 3.1.4; Cox et al., 2010). Ignoring sample 200, 27.5 million trimmed $( \pm 2.66$ million) reads per sample were available for mapping; 15.7 million trimmed reads were available for sample 200. Reads were mapped to the umd3.1 bovine genome reference assembly using STAR aligner (v. 2.5.0b; Dobin et al., 2013) in 2-pass mode. Unannotated splice sites discovered in the first pass were filtered to reject junctions covered by fewer than 4 uniquely mapped reads, showing an overlap of $<5$ nucleotides with flanking exons, and observed in fewer than 4 samples of any given treatment group. Curated junctions were combined with the splice junctions annotated in the reference assembly for the second-read mapping pass, where discovery of novel junctions was disabled. Ignoring sample 200, $73.9 \%( \pm 4.3 \%)$ of the reads were mapped to unique locations, while $21.6 \%$ $( \pm 3.74 \%)$ were too short to be mapped successfully. Only $18.5 \%$ of reads from sample 200 were uniquely mapped, and $77.5 \%$ were too short for mapping. For each sample, the counts of uniquely mapped reads, reads mapped per gene, and gene length was determined with featureCounts (v. 1.5.0; Liao et al., 2014) and custom scripts.

Differential expression of genes was analyzed by both DESeq2 (Love et al., 2014) and edgeR (Robinson et al., 2009; Chen et al., 2014), using the statistical computing software $\mathrm{R}$ (version 3.2.2) to determine the most appropriate statistical package. A 2-way ANOVA model was used with DESeq2, and the model used with edgeR allowed comparisons both between and within subjects. Low read counts were filtered $(\geq 5$ reads per million in $\geq 3$ samples per risk group), which retained $34 \%$ of genes for analysis $(\mathrm{n}=9,813$ for edge $\mathrm{R}$, and $\mathrm{n}=9,800$ for DESeq2, of 28,538). The interaction between risk and week, the effect of risk at each time point (d0, wk 1 , and wk 4 post-calving), and the overall effect of risk across all weeks was determined using both packages. There was no interaction between risk and week with either package. Therefore, the overall effect of risk was analyzed across all time points. Significant differential expression was defined as false discovery rate (FDR) $<5 \%$ and $\mid \log$ fold change $\mid>1$ using edgeR, and FDR $<10 \%$ and $\mid \log$ fold change $\mid=0.4$ using DESeq2. The number of genes differentially expressed was $\mathrm{n}=1,823$ using edgeR and $n=627$ using DESeq2.

The final dispersion estimate was 0.065 for edgeR and 0.175 for DESeq2, with biological coefficients of variation of 26 and $42 \%$, respectively. Therefore, edgeR was deemed more suitable for the differential gene expression analysis than DESeq2. This was due to the 
lower coefficient of variation and the ability to cope with the repeated measures aspect of the data.

\section{Ingenuity Pathway Analysis}

Network and pathway analyses were generated using Ingenuity Pathway Analysis (Ingenuity Systems, Qiagen, Valencia, CA; www.ingenuity.com), which groups differentially expressed genes into known functional pathways and networks based on current knowledge, primarily from rodent and human studies (Krämer et al., 2014). Significantly differentiated genes (FDR < $0.05)$ from the edgeR risk comparison were uploaded to Ingenuity Pathway Analysis, containing Ensembl Gene ID, $P$-value, FDR, and fold change of HR compared with LR. This retained 2,897 analysis-ready molecules for network and function analysis by Ingenuity Pathway Analysis, using default analysis settings. Up- and downregulated genes were analyzed simultaneously. Analysis focused on pathways involved in hematological system development and function, as well as networks involved in immunological or metabolic disease.

\section{Gene Expression Validation}

For validation purposes, 5 genes were requantified using reverse transcriptase-quantitative PCR. Total RNA $(2 \mu \mathrm{g})$ from each sample was reverse transcribed using a Superscript III Supermix kit (Life Technologies) with random pentadecamer primers (Integrated DNA Technologies, Singapore) at a final concentration of $27 \mu \mathrm{M}$. Reverse transcriptase negative controls were also generated by excluding the enzyme, and cDNA samples were stored at $-20^{\circ} \mathrm{C}$. Gene expression was undertaken using a LightCycler 480 instrument (Roche, Basel, Switzerland) and Microfluidics 96.96 Dynamic Array integrated fluidic circuit chips (Fluidigm, San Francisco, CA). Roche Universal Probe Library assays and custom-designed primers were used for gene expression analysis. Primers were designed using publicly available bovine gene sequences (National Center for Biotechnology Information; www.ncbi.nlm.nih.gov) and Roche UPL design software to span intron-exon boundaries when possible. Assay information is presented in Table 1.

Transcripts were normalized to the geometric mean of 2 endogenous control genes (RPL19 and YWHAZ), which were previously identified as suitable reference genes, using GeNorm and Normfinder software (Crookenden et al., 2017). Gene expression fold changes between HR and LR groups were calculated using the $\Delta \Delta \mathrm{Cp}$ method using a repeated-measures ANOVA including week and group as fixed effects and cow as random effect using Proc Mixed in SAS version 9.3.

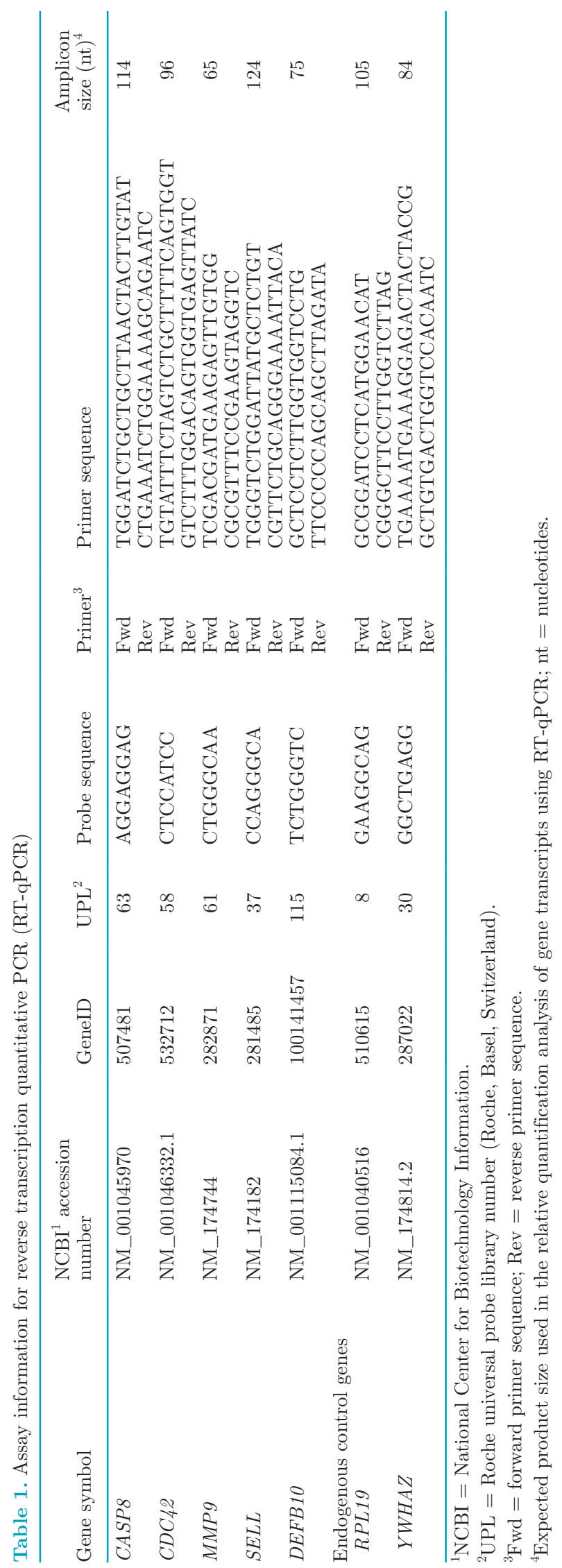


Risk groups were compared with each other across weeks, and statistical significance was considered at $P$ $\leq 0.05$ (Table 2).

\section{RESULTS AND DISCUSSION}

Elevated concentrations of plasma NEFA, BHB, and liver TAG during the peripartum period are associated with an increased risk of metabolic and infectious disease (McArt et al., 2013; Ospina et al., 2013). Furthermore, altered neutrophil function during the transition period also contributes to increased risk of periparturient disease (Cai et al., 1994). We have previously established that neutrophil gene expression changes during transition from pregnancy to lactation (Crookenden et al., 2016); however, the effects of high circulating NEFA, BHB, and liver TAG post-calving on neutrophil gene expression in vivo are unknown. Here, we aim to establish a molecular basis for the effect of metabolic stress neutrophil dysfunction during the transition period.

Our analysis indicated that neutrophils from HR cows had transcriptional changes consistent with reduced function (Figures 2, 3, and 4), which may increase the risk of infectious disease during the peripartum period in these animals. Genes regulating neutrophil recruitment and migration, as well as those involved in interferon signaling, were downregulated in HR cows, suggesting that the neutrophil inflammatory response will not be as efficient in these cows as in LR cows. Circulating neutrophils from the HR cows demonstrated an increased life span, due to a downregulation of genes involved in apoptosis and an increased expression of genes that regulate cell survival. These changes are also evident during infection and inflammation processes and can lead to a detrimental chronic inflammatory state (Medzhitov, 2008).

\section{Recruitment of Neutrophils}

Genes involved in the recruitment of neutrophils were downregulated in neutrophils from the HR animals (Table 3), which resulted in a decrease in the process of granulocyte recruitment within the system of hematological development (Figure 2). Rapid recruitment of neutrophils to the site of tissue injury is essential for phagocytosis and destruction of pathogens. For example, reduced capacity for neutrophil recruitment during the transition period has been associated with increased risk of mastitis (Burton and Erskine, 2003). In fact, there is an inverse relationship between the capacity for neutrophils to be recruited to the udder and the outcome of a mastitis infection (Shuster et al., 1996). Lower expression of C5AR1, CXCR2, and SELL in neutrophils from the HR cows compared with the LR cows (Figure 2) further supports a reduced capacity for attachment and migration of neutrophils in the HR cows and an increased risk of infectious disease. The gene C5AR1, which encodes complement C5a receptor 1 , was 2.6-fold downregulated in the HR cows compared with the LR. Differential expression of C5AR1 has been demonstrated in several studies of mastitis in cattle, confirming that downregulation likely increases susceptibility to mastitis (Ogorevc et al., 2009). Furthermore, Seo et al. (2013) reported a decrease in C5AR1, CXCR2, and SELL in neutrophils soon after calving, indicating a reduced capacity for attachment and migration during the peripartum period. A further indication that neutrophil recruitment is downregulated in HR animals was the downregulation of gene expression

Table 2. Fold change (FC) differences of selected genes in neutrophils of high-risk (HR) cows using RNA sequencing (RNAseq) and reverse transcription-quantitative PCR (RT-qPCR $)^{1}$

\begin{tabular}{|c|c|c|c|c|c|c|c|c|}
\hline Gene & \multicolumn{2}{|c|}{ RNAseq } & \multicolumn{3}{|c|}{ LightCycler 480} & \multicolumn{3}{|c|}{ Fluidigm IFC } \\
\hline$M M P 9$ & -1.35 & 0.50 & -2.42 & 0.49 & $<0.05$ & -3.16 & 0.60 & $<0.05$ \\
\hline SELL & -1.67 & $<0.01$ & -1.45 & 0.59 & 0.39 & -1.26 & 0.46 & 0.50 \\
\hline$D E F B 10$ & -1.64 & 0.15 & -10.50 & 0.79 & $<0.01$ & -3.01 & 1.51 & 0.32 \\
\hline
\end{tabular}

${ }^{1}$ Fold change was calculated as gene expression in neutrophils from HR cows compared with those from the low-risk (LR) group. The RNA sequencing fold changes and statistical significance after multiple testing correction [false discovery rate (FDR)] was calculated using the edgeR package and $\mathrm{R}$ (version 3.4.1) statistical software. Gene expression using RT-qPCR was calculated using the $\Delta \Delta \mathrm{Cp}$ method. Genes were normalized to the geometric mean of 2 endogenous control genes (RPL19 and $Y W H A Z$ ). Statistical significance ( $P$-value) between risk groups was determined by comparing groups across weeks using a repeated measures ANOVA. Gene expression was undertaken using a LightCycler 480 instrument (Roche, Basel, Switzerland) and Microfluidics 96.96 Dynamic Array integrated fluidic circuit (IFC) chips (Fluidigm, San Francisco, CA). ${ }^{2}$ Correlation coefficient between RNAseq and the 2 methods of RT-qPCR. 
of heat shock proteins HSP90 and HSP90AA1 (Figure 3). Inhibition of Hsp90 inhibits recruitment and activation of neutrophils (Tukaj et al., 2015a, 2015b). Therefore, the direction of change indicates aberrant neutrophil migration in high-risk animals. Overall, our results extend these previous findings by indicating that neutrophil recruitment is downregulated to a greater degree in cows at a high risk of metabolic dysfunction, implying that neutrophil function is impaired in these cows and, probably, that they are at an increased risk of peripartum infectious diseases.

\section{Apoptosis and Cell Survival}

The genes differentially expressed between risk groups identified alterations in cellular growth and proliferation, and in cell death and survival (Figure 3). Apoptosis and cell death were decreased in HR cows; conversely, cell survival and cell viability were increased (Table 3). Furthermore, expression of BCL2, which encodes a potent regulator of cell survival, was greater in HR cows (Figure 4). Neutrophil apoptosis is delayed in response to factors such as pro-inflammatory cytokines (e.g., tumor necrosis factor- $\alpha$ ), bacterial proteins (e.g., LPS), or hypoxia, and in disease conditions such as chronic granulomatous disease (Hsieh et al., 1997; Luo and Loison, 2008; Wright et al., 2013). Therefore, neutrophils encounter these regulatory factors in times of stress and inflammation. The delay in apoptosis is controlled, at least in part, by the downregulation of apoptosis-inducing genes and the upregulation of genes involved in cell survival, such as BCL2 (McCracken

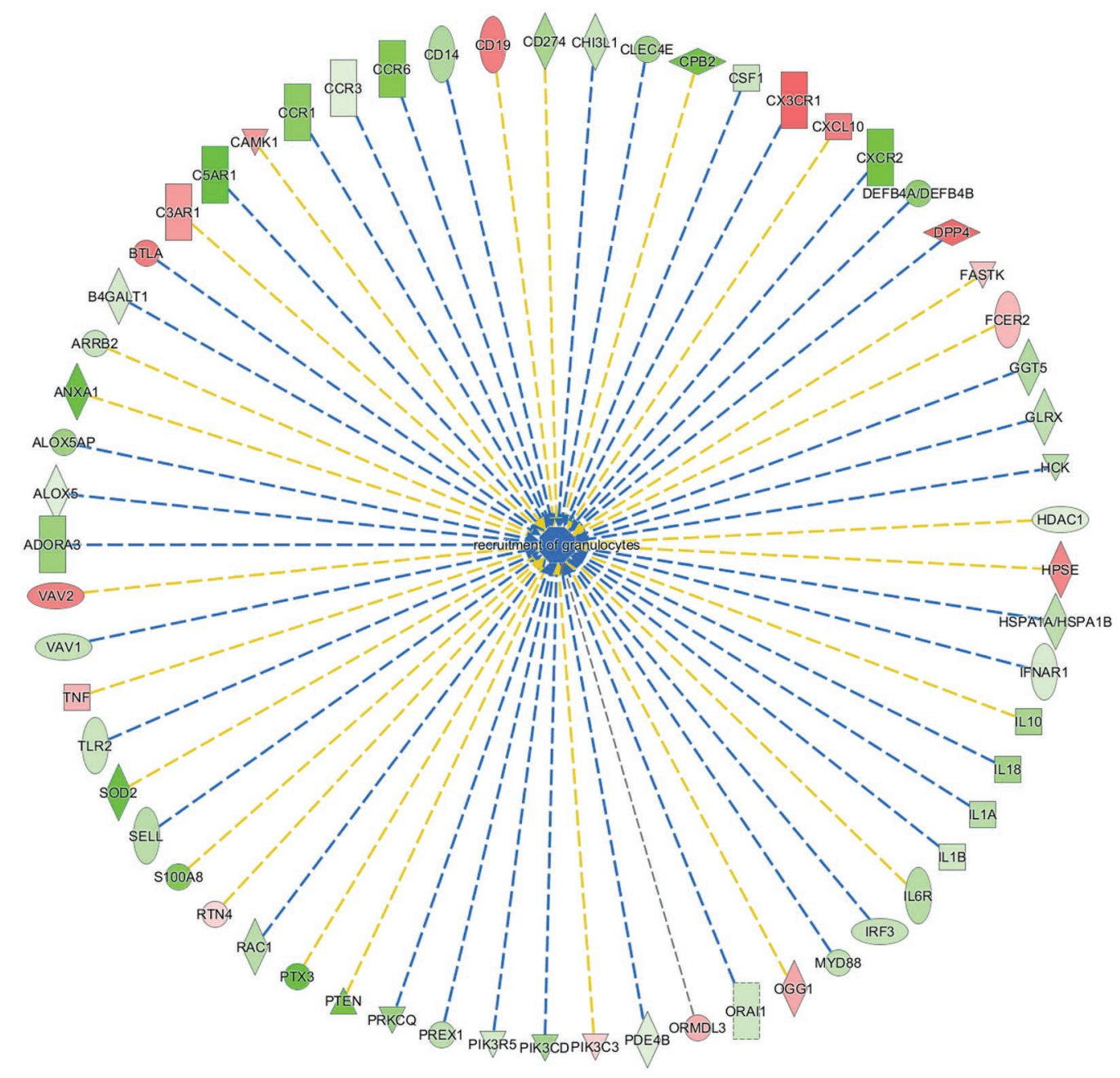

Q 2000-2017 Q1AGEN. All rights reserved.

Figure 2. Genes involved in the recruitment of granulocytes that are differentially expressed in neutrophils of high-risk (HR) cows compared with low-risk (LR) cows. Color intensity indicates the degree of increased (red) or decreased (green) relative expression. Arrows indicate predicted relationships: blue arrows indicate that the molecule leads to activation of granulocyte recruitment, and yellow arrows indicate that the findings are inconsistent in understanding the molecules' relationship with granulocyte recruitment. This figure was generated through the use of IPA (Qiagen Inc., https://www.qiagenbioinformatics.com/products/ingenuity-pathway-analysis). 
and Allen, 2014). Circulating neutrophils from the HR cows demonstrated an overall increase in cell survival and decreased apoptosis, which is likely to exacerbate inflammatory responses, as regulation of neutrophil survival/apoptosis is critical for controlling and resolving inflammation.

\section{Interferon Signaling}

Neutrophil expression of genes involved in IFN signaling was lower in the HR cows than in the LR cows, which suggests a reduced capacity to respond to IFN- $\gamma$ as an attempt to attenuate inflammation (Table 3). Expression of the genes encoding IFN- $\gamma$ receptor (IFNGR1 and IFNGR2) as well as signaling molecule STAT1 and IFN-signaling target genes (IFITM2, IFITM, IFIT1, $M X 1, G 1 P 2$, and IRF9) were lower in HR cows than in LR animals (Figure 4). The IFN signaling pathway confers viral resistance and has roles in innate immune regulation. Aberrant activation of the IFN signaling pathway in neutrophils occurs in cases of inflammatory disease (for example, rheumatoid arthritis) and neuroinflammatory diseases, such as Parkinson's disease and multiple sclerosis (Wright et al., 2015; Yan et al., 2018). As such, therapies to regulate IFN signaling are of interest to ameliorate disease symptoms, demonstrating the importance of IFN signaling in the pathogenesis of proinflammatory disease (Shuai and Liu, 2003). The ability of a cell to respond to IFN is dependent on the expression of its receptor on the cell surface (Kumaran et al., 2007; De Weerd and Nguyen, 2012). Therefore, gene expression of IFN receptors and subsequent expression on the neutrophil cell membrane are essential for fast response to pathogen invasion. Subsequent expression of target genes (IFN response genes) is required for an innate immune response, which is essential for

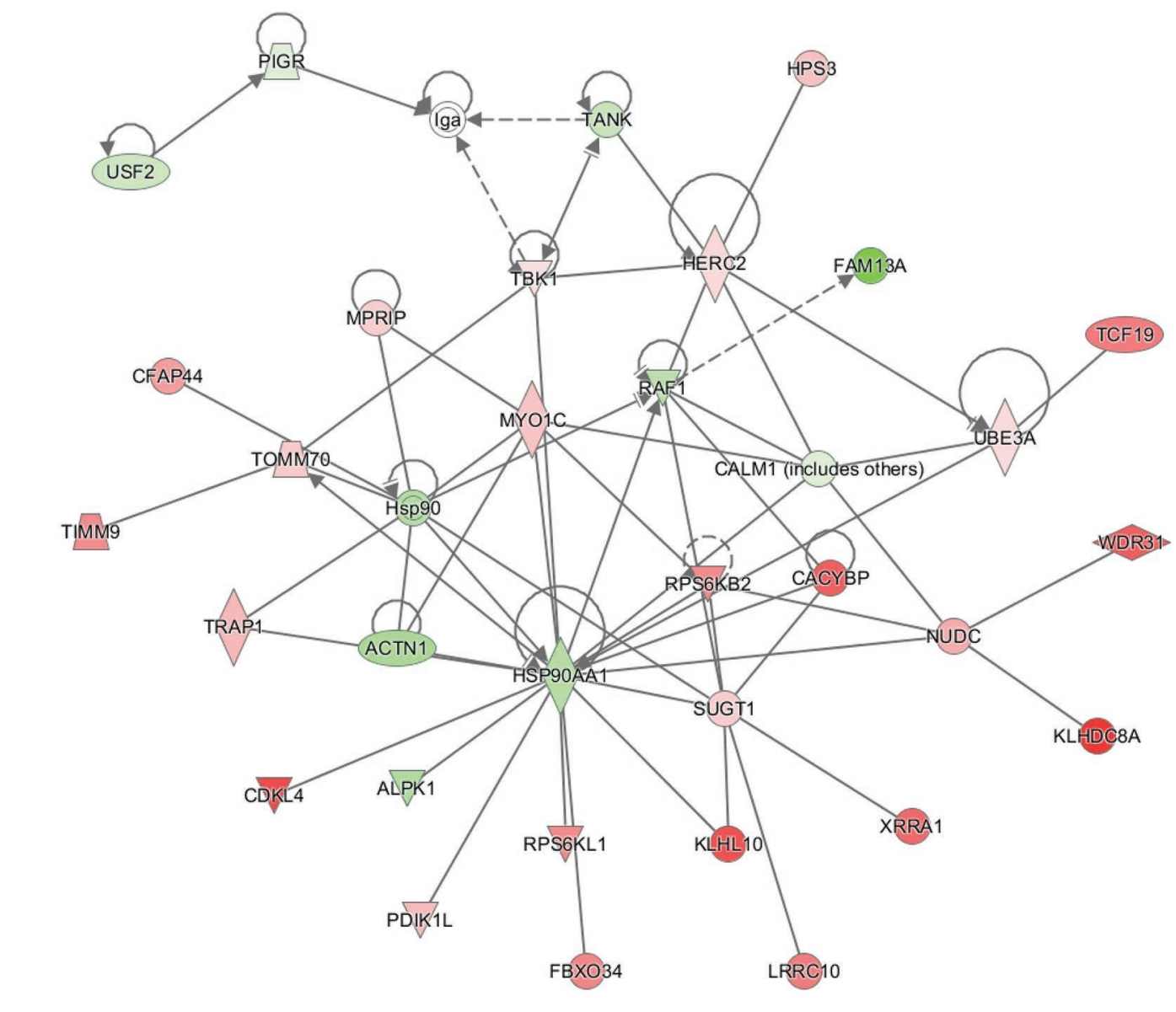

(2000-2017 QIAGEN. All rights reserved

Figure 3. Genes involved in cell signaling, cell death, and cell survival that are differentially expressed in high-risk (HR) cows compared with low-risk (LR) cows. Color intensity indicates the degree of increased (red) or decreased (green) relative expression. Absence of color indicates genes that were not differentially expressed. This network was generated through the use of IPA (QIAGEN Inc., https://www .qiagenbioinformatics.com/products/ingenuity-pathway-analysis). 


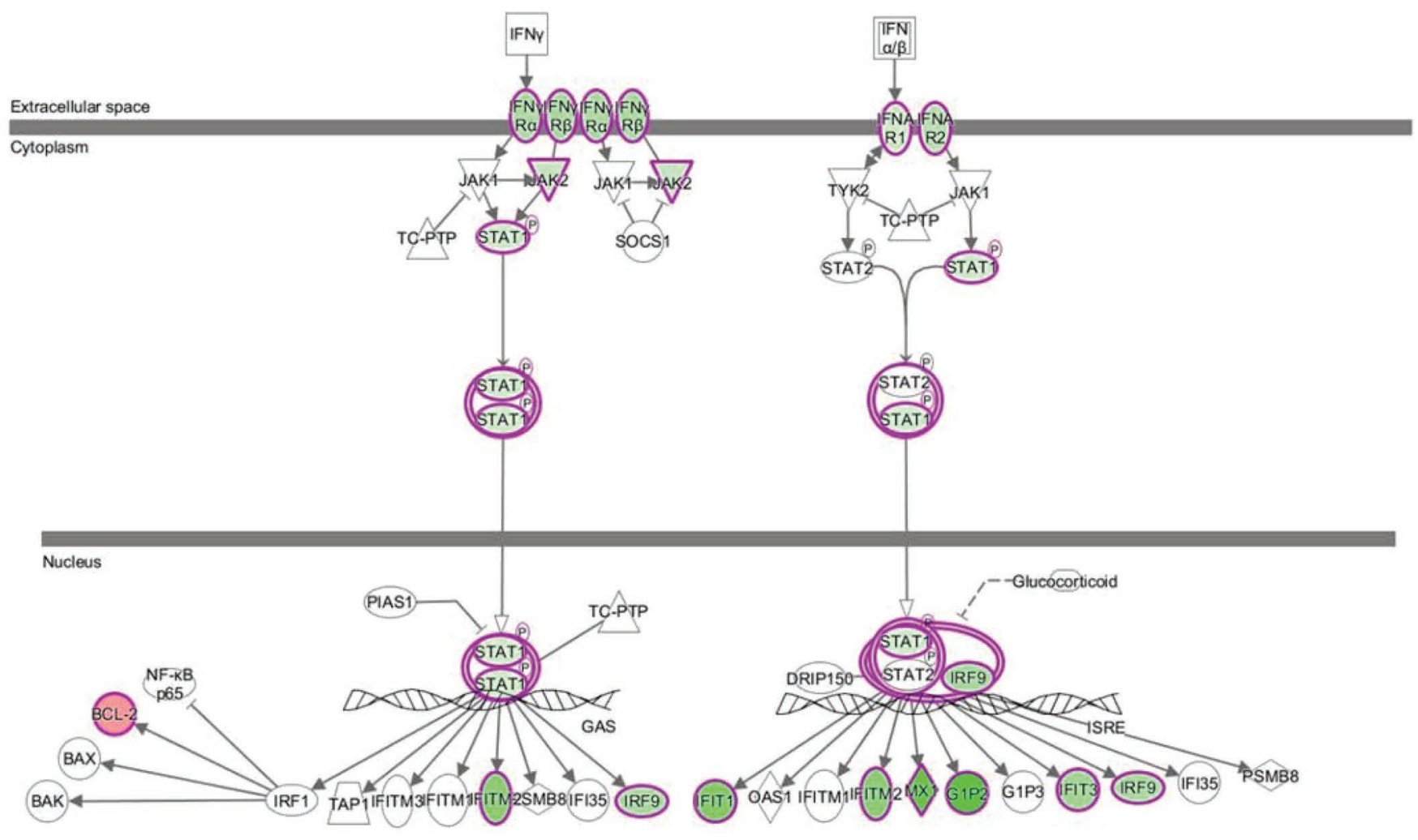

- 2000-2017 OAAGEN. All nonts reserved

Figure 4. Genes within the interferon signaling canonical pathway of Ingenuity Pathway Analysis, with differential gene expression in neutrophils of high-risk (HR) cows compared with low-risk (LR) cows. Color intensity indicates the degree of increased (red) or decreased (green) relative expression in the HR group. Absence of color indicates genes that were not differentially expressed. This pathway was generated through the use of IPA (Qiagen Inc., https://www.qiagenbioinformatics.com/products/ingenuity-pathway-analysis).

clearance of a pathogen. For example, the interferoninducible transmembrane proteins (IFITM) 1, 2, and 3 are critical for inhibiting replication of several virus strains (Brass et al., 2009). Furthermore, neutrophils require $M X 1$ expression (encodes myxovirus resistance protein 1) to contribute to influenza-related lethality, as demonstrated in an IFN signaling-knockout mouse model (Pillai et al., 2016). Therefore, it is conceivable that downregulation of genes involved in the interferon signaling pathway in neutrophils from HR cows may result in increased susceptibility to infection, particularly viral infection, due to an impaired response to interferon signaling. An investigation of protein expression profiles will be required to confirm this hypothesis.

Table 3. Relevant functions within the categories of hematological system development and function, cell death and survival, and canonical pathways that were differentially regulated between the risk groups $(\mathrm{HR}=\mathrm{high} \text { risk; } \mathrm{LR}=\text { low risk })^{1}$

\begin{tabular}{llr}
\hline Category & Function & $P$-value \\
\hline Functions decreased in HR cows & & \\
Hematological system development and function & Recruitment of granulocytes & $6.80 \mathrm{E}-06$ \\
Cell death and survival & Cell death & $-2.17 \mathrm{E}-14$ \\
Cell death and survival & Apoptosis & -3.842 \\
Cell death and survival & Cell death of myeloid cells & -2.194 \\
Cell death and survival & Apoptosis of myeloid cells & $1.17 \mathrm{E}-13$ \\
Canonical pathway & Interferon signaling & -2.497 \\
Functions increased in HR cows & Cell survival & $-2.56 \mathrm{E}-06$ \\
Cell death and survival & Cell viability & $-3.78 \mathrm{E}-04$ \\
Cell death and survival & & $3.80 \mathrm{E}-12$ \\
\hline
\end{tabular}

${ }^{1} P$-values were calculated using Fisher's exact test and are considered significant at $P<0.01$. The activation score $(Z$-score) indicates predicted "direction" of the function (negative = inhibited, positive = activated) based on known relationships between molecules. 


\section{Evidence that Metabolic Stress Contributes to Neutrophil Dysfunction}

Comparison of the transcriptome profiles of neutrophils from HR and LR cows indicates effects of metabolic state on neutrophil gene expression. One of the top 25 networks identified included genes involved in the "Diseases and Functions" of metabolic disease, organismal injury and abnormalities, and hereditary disease (Figure 5). Differential expression of these genes indicates perturbation in the neutrophil inflammatory response - for instance, increased expression of $A B R, D O C K 10, E L M O 3$, and COG genes associated with signal transduction and inflammatory processes, and decreased expression of RAC1 and ELMO2 that are also linked to immune cell activation. The active breakpoint cluster-related protein (encoded by $A B R$ ) has roles in negatively regulating the neutrophil inflammatory response, neutrophil degranulation, and neutrophil extravasation (Cunnick et al., 2009; Deronic et al., 2014). Similarly, the protein products of $R A C 1$, DOCK10, and ELMO, ELMO2, and ELMO3 (engulf- ment and motility proteins), are involved in regulating cell motility and adhesion (Gadea and Blangy, 2014; Schnoor et al., 2017). In addition, COG2, COG5, and COG6 protein products are involved in glycosylation of cell surface receptors required for neutrophil attachment, migration, and cell-cell interactions (Freeze and Schachter, 2009). For example, neutrophil interaction with dendritic cells requires glycosylation of Mac-1 (adhesion molecule CD11b/CD18; van Gisbergen et al., 2005). Several of the differentially expressed genes in this network function in adhesion and migration, which likely indicates a perturbed neutrophil inflammatory response in HR cows.

Several genes upregulated in this network are important for mitochondrial function, such as $C L P B, L A C E 1$, MIGA1, and PMPCB (Saunders et al., 2015; Cesnekova et al., 2016; Zhang et al., 2016; Vögtle et al., 2018). Therefore, dysregulation of these genes may be indicative of metabolic stress. Mitochondria are required for several important processes of neutrophil function, including chemotaxis, phagocytosis, production of reactive oxygen species, and regulation of apoptosis (Fos-

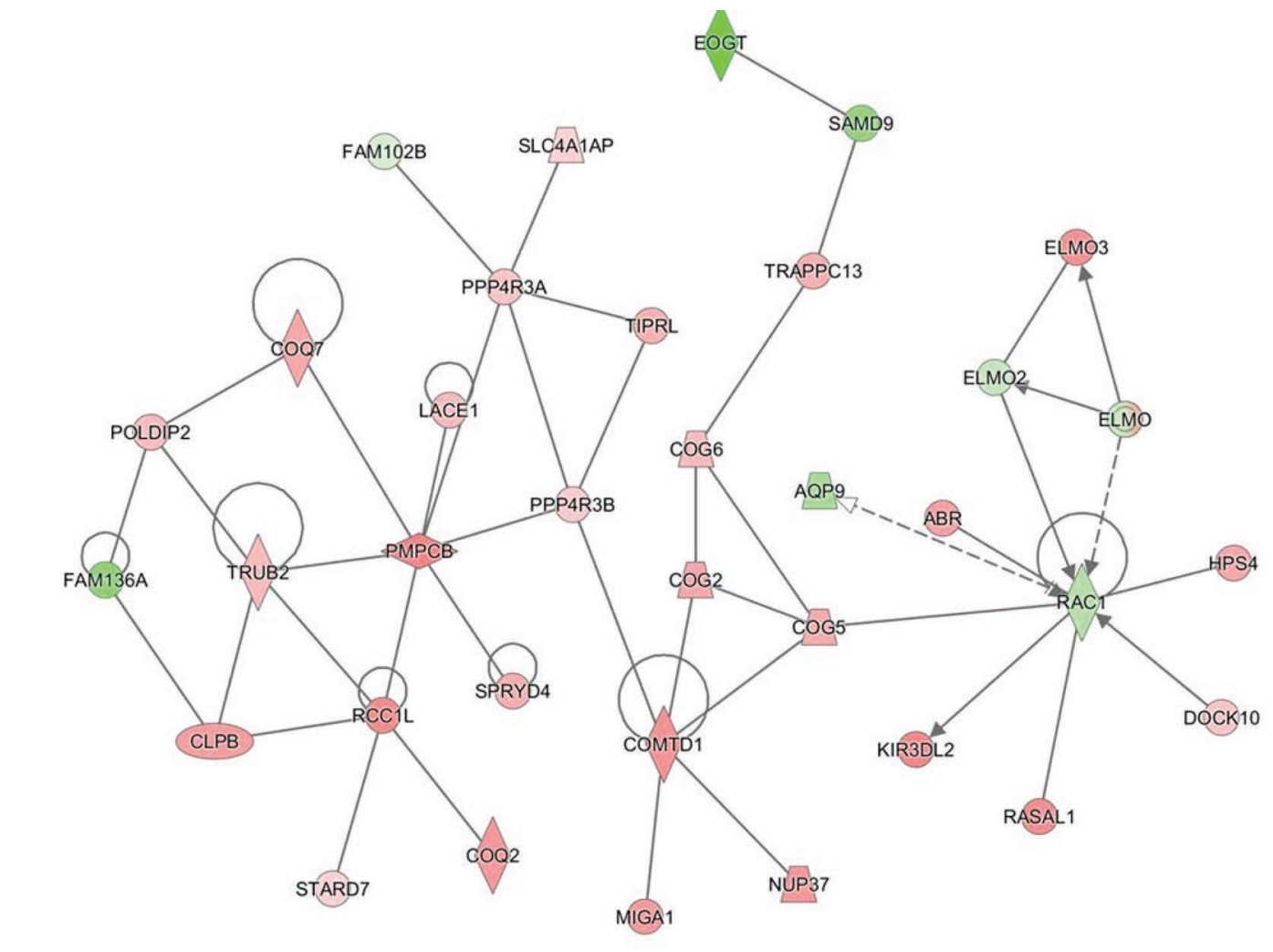

Q 2000-2017 QIAGEN. All rights reserved.

Figure 5. Network of genes involved in metabolic disease that are differentially expressed in neutrophils of high-risk (HR) cows compared with low-risk (LR) cows. This network was given an Ingenuity Pathway Analysis score of 32 and comprises 34 focus molecules. Color intensity indicates the degree of increased (red) or decreased (green) relative expression. Connections between molecules indicate known interactions. This network was generated through the use of IPA (QIAGEN Inc., https://www.qiagenbioinformatics.com/products/ingenuity-pathway-analysis). 
sati et al., 2003). The HR cows were selected for their high concentrations of BHB, NEFA, and liver TAG, all of which have inhibitory effects on neutrophil function. For example, Hoeben et al. (1997) demonstrated that BHB had a small inhibitory effect on oxidative burst in neutrophils from hyperketonemic periparturient cows in vitro (Hoeben et al., 1997). They concluded that high BHB concentrations post-calving might contribute, at least in part, to increased susceptibility to infectious disease during this time (Hoeben et al., 1997). Negative energy balance, the severity of which is indicated by concentrations of circulating NEFA, is negatively correlated with neutrophil function (Hammon et al., 2006). Also, increased liver TAG is associated with decrease in neutrophil function, including downregulation of cell surface adhesion proteins, during the peripartum period (Zerbe et al., 2000). It is likely that the model of metabolic stress is affecting neutrophil function, and there is evidence to indicate that high concentrations of NEFA, BHB, and liver TAG do have an effect on neutrophil function.

\section{CONCLUSIONS}

The results presented here highlight a link between subclinical metabolic health dysfunction and peripartal innate immune dysfunction, and support the hypothesis that nonclinical metabolic stress contributes to immunosuppression during the periparturient period. We have established that neutrophils from cows with metabolic stress have an altered transcriptome, which could play a key role in the effectiveness of the innate immune response. These changes indicate reduced immunological function associated with metabolic stress and, likely, increased susceptibility to infectious disease during the transition period for dairy cows. Further exploration of the link between peripartal immune dysfunction and metabolic stress will provide insight that may be exploited for therapeutic intervention among animals that are likely to develop clinical disease from underlying subclinical disease.

\section{ACKNOWLEDGMENTS}

The authors acknowledge the technical and farm staff at Scott Farm (DairyNZ Ltd., Hamilton, New Zealand) for animal handing and blood sampling. New Zealand Genomics Ltd. completed RNA sequencing for the project. Computation for this project was supported by the New Zealand eScience Infrastructure (NeSI; Auckland, New Zealand). This work was supported by funding from New Zealand dairy farmers through DairyNZ Inc. (RD1403; Hamilton, New Zealand), the Ministry of Business, Innovation and Employment (Wellington,
New Zealand; DRCX1201), and the Maryland Agricultural Experiment Station.

\section{REFERENCES}

Andrews, S. 2010. FastQC: A quality control tool for high throughput sequence data.

Blaak, E. E. 2003. Fatty acid metabolism in obesity and type 2 diabetes mellitus. Proc. Nutr. Soc. 62:753-760. https://doi.org/10 .1079/PNS2003290.

Brass, A. L., I. C. Huang, Y. Benita, S. P. John, M. N. Krishnan, E. M. Feeley, B. J. Ryan, J. L. Weyer, L. van der Weyden, E. Fikrig, D. J. Adams, R. J. Xavier, M. Farzan, and S. J. Elledge. 2009. The IFITM proteins mediate cellular resistance to influenza A H1N1 virus, West Nile virus, and dengue virus. Cell 139:1243-1254. https://doi.org/10.1016/j.cell.2009.12.017.

Burton, J. L., and R. J. Erskine. 2003. Immunity and mastitis. Some new ideas for an old disease. Vet. Clin. North Am. Food Anim. Pract. 19:1-45. https://doi.org/10.1016/0749-0720(02)00073-7.

Burton, J. L., M. E. Kehrli Jr., and R. L. Horst. 1995. Regulation of L-selectin and CD18 on bovine neutrophils by glucocorticoids: Effects of cortisol and dexamethasone. J. Leukoc. Biol. 57:317-325.

Burton, J. L., S. A. Madsen, J. Yao, S. S. Sipkovsky, and P. M. Coussens. 2001. An immunogenomics approach to understanding periparturient immunosuppression and mastitis susceptibility in dairy cows. Acta Vet. Scand. 42:407-424.

Cai, T. Q., P. G. Weston, L. A. Lund, B. Brodie, D. J. McKenna, and W. C. Wagner. 1994. Association between neutrophil functions and periparturient disorders in cows. Am. J. Vet. Res. 55:934-943.

Cesnekova, J., J. Spacilova, H. Hansikova, J. Houstek, J. Zeman, and L. Stiburek. 2016. LACE1 interacts with p53 and mediates its mitochondrial translocation and apoptosis. Oncotarget 7:4768747698. https://doi.org/10.18632/oncotarget.9959.

Challis, J. R., C. J. Lockwood, L. Myatt, J. E. Norman, J. F. Strauss, and F. Petraglia. 2009. Inflammation and pregnancy. Reprod. Sci. 16:206-215. https://doi.org/10.1177/1933719108329095.

Chen, Y., D. McCarthy, M. Robinson, and G. K. Smyth. 2014. edgeR : Differential expression analysis of digital gene expression data. User's Guide.

Christiaens, I., D. B. Zaragoza, L. Guilbert, S. A. Robertson, B. F. Mitchell, and D. M. Olson. 2008. Inflammatory processes in preterm and term parturition. J. Reprod. Immunol. 79:50-57. https:/ /doi.org/10.1016/j.jri.2008.04.002.

Compton, C. W. R., S. McDougall, L. Young, and M. A. Bryan. 2014. Prevalence of subclinical ketosis in mainly pasture-grazed dairy cows in New Zealand in early lactation. N. Z. Vet. J. 62:30-37. https://doi.org/10.1080/00480169.2013.823829.

Cox, M. P., D. A. Peterson, and P. J. Biggs. 2010. SolexaQA: At-aglance quality assessment of Illumina second-generation sequencing data. BMC Bioinformatics 11:485. https://doi.org/10.1186/ 1471-2105-11-485.

Crookenden, M. A., A. Heiser, A. Murray, V. S. R. Dukkipati, J. K. Kay, J. J. Loor, S. Meier, M. D. Mitchell, K. M. Moyes, C. G. Walker, and J. R. Roche. 2016. Parturition in dairy cows temporarily alters the expression of genes in circulating neutrophils. J. Dairy Sci. 99:6470-6483. https://doi.org/10.3168/jds.2015-10877.

Crookenden, M. A., C. G. Walker, B. Kuhn-Sherlock, A. Murray, V. S. R. Dukkipati, A. Heiser, and J. R. Roche. 2017. Technical note: Evaluation of endogenous control gene expression in bovine neutrophils by reverse-transcription quantitative PCR using microfluidics gene expression arrays. J. Dairy Sci. 100:6763-6771. https:// doi.org/10.3168/jds.2016-12460.

Cunnick, J. M., S. Schmidhuber, G. Chen, M. Yu, S.-J. Yi, Y. J. Cho, V. Kaartinen, P. Minoo, D. Warburton, J. Groffen, and N. Heisterkamp. 2009. Bcr and Abr cooperate in negatively regulating acute inflammatory responses. Mol. Cell. Biol. 29:5742-5750. https://doi .org/10.1128/MCB.00357-09.

de Weerd, N. A., and T. Nguyen. 2012. The interferons and their receptors-Distribution and regulation. Immunol. Cell Biol. 90:483491. https://doi.org/10.1038/icb.2012.9. 
Deronic, A., S. Helmersson, T. Leanderson, and F. Ivars. 2014. The quinoline-3-carboxamide paquinimod (ABR-215757) reduces leukocyte recruitment during sterile inflammation: Leukocyte- and context-specific effects. Int. Immunopharmacol. 18:290-297. https: //doi.org/10.1016/j.intimp.2013.12.008.

Desideri-Vaillant, V., L. Bordier, S. Gidenne, O. Dupuy, F. Ceppa, H. Mayaudon, B. Bauduceau, and P. Burnat. 2004. Value of nonesterified fatty acids quantification in diabetes. Ann. Biol. Clin. (Paris) 62:177-182

Dobin, A., C. A. Davis, F. Schlesinger, J. Drenkow, C. Zaleski, S. Jha, P. Batut, M. Chaisson, and T. R. Gingeras. 2013. STAR: Ultrafast universal RNA-seq aligner. Bioinformatics 29:15-21. https://doi .org/10.1093/bioinformatics/bts635.

Drackley, J. K. 1999. Biology of dairy cows during the transition period: The final frontier? J. Dairy Sci. 82:2259-2273. https://doi .org/10.3168/jds.S0022-0302(99)75474-3.

Farney, J. K., L. K. Mamedova, J. F. Coetzee, B. KuKanich, L. M. Sordillo, S. K. Stoakes, J. E. Minton, L. C. Hollis, and B. J. Bradford. 2013. Anti-inflammatory salicylate treatment alters the metabolic adaptations to lactation in dairy cattle. Am. J. Physiol. Regul. Integr. Comp. Physiol. 305:R110-R117. https://doi.org/10 .1152 /ajpregu.00152.2013.

Fossati, G., D. A. Moulding, D. G. Spiller, R. J. Moots, M. R. White, and S. W. Edwards. 2003. The mitochondrial network of human the mitochondrial network of human neutrophils: Role in chemotaxis, phagocytosis, respiratory burst activation, and commitment to apoptosis. J. Immunol. 170:1964-1972. https://doi.org/10 .4049/jimmunol.170.4.1964.

Freeze, H., and H. Schachter. 2009. Genetic disorders of glycosylation. 2nd ed. A. Varki, R. Cummings, and J. Esko, ed. Cold Spring Harbor Laboratory Press, Cold Spring Harbor, NY.

Gadea, G., and A. Blangy. 2014. Dock-family exchange factors in cell migration and disease. Eur. J. Cell Biol. 93:466-477. https://doi .org/10.1016/j.ejcb.2014.06.003.

Hammon, D. S., I. M. Evjen, T. R. Dhiman, J. P. Goff, and J. L. Walters. 2006. Neutrophil function and energy status in Holstein cows with uterine health disorders. Vet. Immunol. Immunopathol. 113:21-29. https://doi.org/10.1016/j.vetimm.2006.03.022.

Hammon, D. S., and J. P. Goff. 2006. Immune function and energy status in Holstein cows with uterine infections. Pages 29-36 in Mid-South Ruminant Nutrition Conference, Arlington, VA. Texas Animal Nutrition Council.

Heiser, A., A. Mccarthy, N. Wedlock, S. Meier, J. Kay, C. Walker, M. A. Crookenden, M. D. Mitchell, S. Morgan, K. Watkins, J. J. Loor, and J. R. Roche. 2015. Grazing dairy cows had decreased interferon- $\gamma$, tumor necrosis factor, and interleukin-17, and increased expression of interleukin-10 during the first week after calving. J. Dairy Sci. 98:937-946. https://doi.org/10.3168/jds .2014-8494.

Hoeben, D., R. Heyneman, and C. Burvenich. 1997. Elevated levels of beta-hydroxybutyric acid in periparturient cows and in vitro effect on respiratory burst activity of bovine neutrophils. Vet. Immunol. Immunopathol. 58:165-170. https://doi.org/10.1016/S0165 $-2427(97) 00031-7$.

Hsieh, S. C., M. H. Huang, C. Y. Tsai, Y. Y. Tsai, S. T. Tsai, K. H. Sun, H. S. Yu, S. H. Han, and C. L. Yu. 1997. The expression of genes modulating programmed cell death in normal human polymorphonuclear neutrophils. Biochem. Biophys. Res. Commun. 233:700-706

Kehrli, M. E. Jr., B. J. Nonnecke, and J. A. Roth. 1989. Alterations in bovine neutrophil function during the periparturient period. Am. J. Vet. Res. 50:207-214.

Kimura, K., J. P. Goff, M. E. Kehrli, and T. A. Reinhardt. 2002. Decreased neutrophil function as a cause of retained placenta in dairy cattle. J. Dairy Sci. 85:544-550. https://doi.org/10.3168/jds S0022-0302(02)74107-6.

Krämer, A., J. Green, J. Pollard, and S. Tugendreich. 2014. Causal analysis approaches in Ingenuity Pathway Analysis. Bioinformatics 30:523-530. https://doi.org/10.1093/bioinformatics/btt703.
Kumaran, J., L. Wei, L. P. Kotra, and E. N. Fish. 2007. A structural basis for interferon-alpha-receptor interactions. FASEB J. 21:3288-3296. https://doi.org/10.1096/fj.07-8585com.

LeBlanc, S. 2010. Monitoring metabolic health of dairy cattle in the transition period. J. Reprod. Dev. 56(Suppl):S29-S35.

Liao, Y., G. K. Smyth, and W. Shi. 2014. FeatureCounts: An efficient general purpose program for assigning sequence reads to genomic features. Bioinformatics 30:923-930. https://doi.org/10.1093/ bioinformatics/btt656.

Love, M. I., W. Huber, and S. Anders. 2014. Moderated estimation of fold change and dispersion for RNA-seq data with DESeq2. Genome Biol. 15:550. https://doi.org/10.1186/s13059-014-0550-8.

Luo, H. R., and F. Loison. 2008. Constitutive neutrophil apoptosis: mechanisms and regulation. Am. J. Hematol. 83:288-295. https:// doi.org/10.1002/ajh.21078.

Martin, M. 2011. Cutadapt removes adapter sequences from highthroughput sequencing reads. EMBnet Journal 17:10-12.

McArt, J. A., D. V. Nydam, G. R. Oetzel, T. R. Overton, and P. A. Ospina. 2013. Elevated non-esterified fatty acids and $\beta$-hydroxybutyrate and their association with transition dairy cow performance. Vet. J. 198:560-570. https://doi.org/10.1016/j.tvjl .2013.08.011.

McCracken, J. M., and L.-A. H. Allen. 2014. Regulation of human neutrophil apoptosis and lifespan in health and disease. J. Cell Death 7:15-23. https://doi.org/10.4137/JCD.S11038.

Medzhitov, R. 2008. Origin and physiological roles of inflammation. Nature 454:428-435. https://doi.org/10.1038/nature07201.

Molloy, E. J., A. J. O. Neill, J. J. Grantham, M. Sheridan-Pereira, J. M. Fitzpatrick, D. W. Webb, and R. W. Watson. 2004. Labor induces a maternal inflammatory response syndrome. Am. J. Obstet. Gynecol. 190:448-455. https://doi.org/10.1016/j.ajog.2003.08.027.

Ogorevc, J., T. Kunej, A. Razpet, and P. Dovc. 2009. Database of cattle candidate genes and genetic markers for milk production and mastitis. Anim. Genet. 40:832-851. https://doi.org/10.1111/j .1365-2052.2009.01921.x.

Ospina, P. A.. J. A. McArt, T. R. Overton, T. Stokol, and D. V. Nydam. 2013. Using nonesterified fatty acids and beta-hydroxybutyrate concentrations during the transition period for herd-level monitoring of increased risk of disease and decreased reproductive and milking performance. Vet. Clin. North Am. Food Anim. Pract. 29:387-412. https://doi.org/10.1016/j.cvfa.2013.04.003.

Pillai, P. S., R. D. Molony, K. Martinod, H. Dong, I. K. Pang, M. C. Tal, A. G. Solis, P. Bielecki, S. Mohanty, M. Trentalange, R. J. Homer, R. A. Flavell, D. D. Wagner, R. R. Montgomery, A. C. Shaw, P. Staeheli, and A. Iwasaki. 2016. Mx1 reveals innate pathways to antiviral resistance and lethal influenza disease. Science. 352:463-466. https://doi.org/10.1126/science.aaf3926.

Pilz, S., and W. März. 2008. Free fatty acids as a cardiovascular risk factor. Clin. Chem. Lab. Med. 46:429-434. https://doi.org/10 .1515/CCLM.2008.118.

Robinson, M. D., D. J. McCarthy, and G. K. Smyth. 2009. edgeR: A Bioconductor package for differential expression analysis of digital gene expression data. Bioinformatics 26:139-140. https://doi.org/ 10.1093/bioinformatics/btp616.

Roche, J. R., P. G. Dillon, C. R. Stockdale, L. H. Baumgard, and M. J. VanBaale. 2004. Relationships among international body condition scoring systems. J. Dairy Sci. 87:3076-3079. https://doi.org/ 10.3168/jds.S0022-0302(04)73441-4.

Sartorelli, P., S. Paltrinieri, and S. Comazzi. 1999. Non-specific immunity and ketone bodies. II: In vitro studies on adherence and superoxide anion production in ovine neutrophils. Zentralbl Veterinarmed A. 46:613-619. https://doi.org/10.1046/j.1439-0442.2000 $.00253 . \mathrm{x}$

Saunders, C., L. Smith, F. Wibrand, K. Ravn, P. Bross, I. Thiffault, M. Christensen, A. Atherton, E. Farrow, N. Miller, S. F. Kingsmore, and E. Ostergaard. 2015. CLPB variants associated with autosomal-recessive mitochondrial disorder with cataract, neutropenia, epilepsy, and methylglutaconic aciduria. Am. J. Hum. Genet. 96:258-265. https://doi.org/10.1016/j.ajhg.2014.12.020. 
Scalia, D., N. Lacetera, U. Bernabucci, K. Demeyere, L. Duchateau, and C. Burvenich. 2006. In vitro effects of nonesterified fatty acids on bovine neutrophils oxidative burst and viability. J. Dairy Sci. 89:147-154. https://doi.org/10.3168/jds.S0022-0302(06)72078-1.

Schnoor, M., A. García Ponce, E. Vadillo, R. Pelayo, J. Rossaint, and A. Zarbock. 2017. Actin dynamics in the regulation of endothelial barrier functions and neutrophil recruitment during endotoxemia and sepsis. Cell. Mol. Life Sci. 74:1985-1997. https://doi.org/10 .1007/s00018-016-2449-x.

Seo, J., J. S. Osorio, and J. J. Loor. 2013. Purinergic signaling gene network expression in bovine polymorphonuclear neutrophils during the peripartal period. J. Dairy Sci. 96:7675-7683. https://doi .org/10.3168/jds.2013-6952.

Shen, Y., L. Chen, W. Yang, and Z. Wang. 2018. Exploration of serum sensitive biomarkers of fatty liver in dairy cows. Sci. Rep. 8:13574. https://doi.org/10.1038/s41598-018-31845-0.

Shuai, K., and B. Liu. 2003. Regulation of JAK-STAT signalling in the immune system. Nat. Rev. Immunol. 3:900-911. https://doi.org/ $10.1038 /$ nri1226.

Shuster, D. E., E. K. Lee, and M. E. Kehrli Jr... 1996. Bacterial growth, inflammatory cytokine production, and neutrophil recruitment during coliform mastitis in cows within ten days after calving, compared with cows at midlactation. Am. J. Vet. Res. 57:1569-1575.

Sordillo, L. M., and S. L. Aitken. 2009. Impact of oxidative stress on the health and immune function of dairy cattle. Vet. Immunol. Immunopathol. 128:104-109. https://doi.org/10.1016/j.vetimm.2008 .10 .305 .

Sordillo, L. M., G. A. Contreras, and S. L. Aitken. 2009. Metabolic factors affecting the inflammatory response of periparturient dairy cows. Anim. Health Res. Rev. 10:53-63. https://doi.org/10.1017/ S1466252309990016.

Sordillo, L. M., and W. Raphael. 2013. Significance of metabolic stress, lipid mobilization, and inflammation on transition cow disorders. Vet. Clin. North Am. Food Anim. Pract. 29:267-278. https://doi .org/10.1016/j.cvfa.2013.03.002.

Suriyasathaporn, W., A. J. J. M. Daemen, E. N. NoordhuizenStassen, S. J. Dieleman, M. Nielen, and Y. H. Schukken. 1999. $\beta$-Hydroxybutyrate levels in peripheral blood and ketone bodies supplemented in culture media affect the in vitro chemotaxis of bovine leukocytes. Vet. Immunol. Immunopathol. 68:177-186. https: //doi.org/10.1016/S0165-2427(99)00017-3.

Tukaj, S., L. Hellberg, C. Ueck, M. Hänsel, U. Samavedam, D. Zillikens, R. J. Ludwig, T. Laskay, and M. Kasperkiewicz. 2015a. Heat shock protein 90 is required for ex vivo neutrophil-driven autoantibody-induced tissue damage in experimental epidermolysis bullosa acquisita. Exp. Dermatol. 24:471-473. https://doi.org/ 10.1111/exd.12680

Tukaj, S., D. Zillikens, and M. Kasperkiewicz. 2015b. Heat shock protein 90: A pathophysiological factor and novel treatment target in autoimmune bullous skin diseases. Exp. Dermatol. 24:567-571. https://doi.org/10.1111/exd.12760.

Vailati-Riboni, M., S. Meier, N. V. Priest, C. R. Burke, J. K. Kay, S. McDougall, M. D. Mitchell, C. G. Walker, M. Crookenden, A. Heiser, J. R. Roche, and J. J. Loor. 2015. Adipose and liver gene expression profiles in response to treatment with a nonsteroidal antiinflammatory drug after calving in grazing dairy cows. J. Dairy Sci. 98:3079-3085. https://doi.org/10.3168/jds.2014-8579.

van Gisbergen, K. P. J. M., M. Sanchez-Hernandez, T. B. H. Geijtenbeek, and Y. van Kooyk. 2005. Neutrophils mediate immune modulation of dendritic cells through glycosylation-dependent interactions between Mac-1 and DC-SIGN. J. Exp. Med. 201:1281-1292. https://doi.org/10.1084/jem.20041276.

Vazquez-Añon, M., S. Bertics, M. Luck, R. R. Grummer, and J. Pinheiro. 1994. Peripartum liver triglyceride and plasma metabolites in dairy cows. J. Dairy Sci. 77:1521-1528. https://doi.org/10 .3168/jds.S0022-0302(94)77092-2.

Vögtle, F. N., B. Brändl, A. Larson, M. Pendziwiat, M. W. Friederich, S. M. White, A. Basinger, C. Kücükköse, H. Muhle, J. A. Jähn, O. Keminer, K. L. Helbig, C. F. Delto, L. Myketin, D. Mossmann, N. Burger, N. Miyake, A. Burnett, A. van Baalen, M. A. Lovell, N. Matsumoto, M. Walsh, H. C. Yu, D. N. Shinde, U. Stephani, J. L. K. Van Hove, F. J. Müller, and I. Helbig. 2018. Mutations in PMPCB encoding the catalytic subunit of the mitochondrial presequence protease cause neurodegeneration in early childhood. Am. J. Hum. Genet. 102:557-573. https://doi.org/10.1016/j.ajhg .2018.02.014.

Wright, H. L., H. B. Thomas, R. J. Moots, and S. W. Edwards. 2013. RNA-seq reveals activation of both common and cytokine-specific pathways following neutrophil priming. PLoS One 8:e58598. https: //doi.org/10.1371/journal.pone.0058598.

Wright, H. L., H. B. Thomas, R. J. Moots, and S. W. Edwards. 2015. Interferon gene expression signature in rheumatoid arthritis neutrophils correlates with a good response to TNFi therapy. Rheumatology (Oxford) 54:188-193. https://doi.org/10.1093/ rheumatology/keu299.

Yan, Z., S. A. Gibson, J. A. Buckley, H. Qin, and E. N. Benveniste. 2018. Role of the JAK/STAT signaling pathway in regulation of innate immunity in neuroinflammatory diseases. Clin. Immunol. 189:4-13. https://doi.org/10.1016/j.clim.2016.09.014.

Zerbe, H., N. Schneider, W. Leibold, T. Wensing, T. A. M. Kruip, and H. J. Schuberth. 2000. Altered functional and immunophenotypical properties of neutrophilic granulocytes in postpartum cows associated with fatty liver. Theriogenology 54:771-786.

Zhang, Y., X. Liu, J. Bai, X. Tian, X. Zhao, W. Liu, X. Duan, W. Shang, H. Y. Fan, and C. Tong. 2016. Mitoguardin regulates mitochondrial fusion through MitoPLD and is required for neuronal homeostasis. Mol. Cell 61:111-124. https://doi.org/10.1016/j .molcel.2015.11.017. 